\title{
Pandemi Covid-19: Apersepsi Mahasiswa PIAUD Terhadap Penerapan Multimedia Ezvid
}

\author{
(The Covid-19 Pandemic: Student of the Department of Islamic Early \\ Childhood Education Aperception on the Implementation of Ezvid \\ Multimedia) \\ Nur Asma ${ }^{1 *}$, Fenny Anggreni ${ }^{2}$ \\ ${ }^{1}$ Pendidikan Islam Anak Usia Dini, Institut Agama Islam Negeri Langsa; ${ }^{2}$ Pendidikan Matematika, Institut \\ Agama Islam Negeri Langsa \\ 1nurasma2905@gmail.com ,2fenny@iainlangsa.ac.id \\ *)corresponding author
}

First received:

01 August 2020

Revised:
07 October 2020

Final Accepted:

31 December 2020

Abstract

The purpose of this study was to determine students' perceptions of the application of Ezvid multimedia in the PIAUD IAIN Langsa Study Program. This research was conducted due to the outbreak of the COVID-19 pandemic where lectures were conducted online in April 2020. So that lecturers need multimedia in teaching to help deliver material to students, one of which is using Ezvid Multimedia. The method in this study uses a descriptive quantitative research approach. Data collection techniques used questionnaires and percentage of data analysis. With a sample of 59 students from the PIAUD study program following the Worship Practices course. The results of this study indicate that most students agree with the implementation of e-learning multimedia based on Ezvid in the Department of Islamic Early Childhood Education, IAIN Langsa. This was evidenced by the percentage value of $61.4 \%$ obtained from the questionnaire results, then almost half of them disagree with a percentage of $27.7 \%$, and a small proportion strongly disagreed with the percentage of $2.9 \%$. If it is seen from the percentage value that most of the students agree with the application of e-learning multimedia based on Ezvid in the PIAUD IAIN Langsa Study Program. So that the response of students to the application of e-learning multimedia based on Ezvid in IAIN Langsa PIAUD Study Program most of the students agree. So that Ezvid multimedia can be applied by lecturers in delivering lectures both online and offline.

Keywords: Student Apperception, Multimedia, Ezvid

\begin{abstract}
Abstrak
Adapun tujuan dalam penelitian ini untuk mengetahui apersepsi mahasiswa terhadap penerapan multimedia Ezvid di Program Studi Pendidikan Islam Anak Usia Dini (PIAUD) IAIN Langsa. Penelitian ini dilakukan karena mewabahnya pandemic COVID19 dimana perkuliahan dilakukan secara daring pada bulan April 2020. Sehingga dosen memerlukan multimedia dalam mengajar untuk membantu penyampaian materi kepada mahasiswa, salah satunya menggunakan multimedia ezvid. Adapun metode dalam penelitian ini menggunakan pendekatan penelitian kuantitatif deskriptif. Teknik pengumpulan data menggunakan angket dan analisis data persentase. Dengan sampel sebanyak 59 mahasiswa dari Program Studi PIAUD yang mengikuti mata kuliah Praktik Ibadah. Adapun hasil dari penelitian ini bahwa sebagian besar mahasiswa setuju dengan diterapkannya multimedia e-learning berbasis Ezvid di Program Studi PIAUD IAIN Langsa, hal ini terbukti dengan nilai persentase $61,4 \%$ yang didapat dari hasil angket, selanjutnya hampir setengahnya tidak setuju dengan persentase $27,7 \%$ dan sebagian kecil yang sangat tidak setuju dengan persentase $2,9 \%$. Jika dilihat dari nilai persentase bahwa sebagian besar mahasiswa setuju dengan penerapan multimedia e-learning
\end{abstract}


berbasis Ezvid di Program Studi PIAUD IAIN Langsa. Sehingga respon mahasiswa terhadap penerapan multimedia e-learning berbasis Ezvid di Program Studi PIAUD IAIN Langsa sebagian besar mahasiswanya setuju. Sehingga multimedia Ezvid bisa diterapkan dosen dalam menyampaikan perkuliahan baik secara daring maupun luring.

Kata Kunci: Apersepsi Mahasiswa, Multimedia, Ezvid

\section{PENDAHULUAN}

Corona virus yang terjadi pada tahun 2019 yang membuat dunia terjadi perubahan yang sangat drastis, baik di bidang ekonomi, kesehatan maupun di bidang pendidikan. Virus Corona atau disebut pula COVID-19 (Corona Virus Disease 2019) pertama kali ditemukan di Kota Wuhan, China pada akhir Desember 2019. Dalam waktu yang sangat singkat, virus ini ternyata telah menular dengan sangat cepat dan menyebar ke hampir semua negara di dunia, termasuk Indonesia (Yusup et al., 2020). Sejumlah pengamat mengkategorikan Covid-19 sebagai salah satu jenis virus yang sangat berbaya dan mematikan.

Orang yang terinfeksi virus Covid19 ditandai akan mengalami gejala flu yang disertai demam, pilek, batuk kering, sakit tenggorokan, dan sakit kepala (Arief Kresna dan Juni Ahyar, 2020). Pandemi global yang terjadi pula di Indonesia membuat banyak pihak berupaya ikut berperan serta dalam mengatasi. Para dokter umum dan spesialis angkat bicara bersama guna memberi penjelasan singkat kepada masyarakat maupun imbauan agar menjaga kebersihan diri dan lingkungan sekaligus tak banyak keluar rumah (Setiawan, 2020).

Langkah-langkah telah dilakukan oleh pemerintah untuk dapat menyelesaikan kasus luar biasa ini, salah satunya adalah dengan mensosialisasikan gerakan Social

Distancing. WHO saat ini telah menetapkan status darurat di tengah meningkatnya jumlah korban tewas akibat virus Corona yang menyerang system pernapasan. WHO pun memberikan panduan untuk mecegah penularan virus yaitu dengan cara menjaga kebersihan, menjaga interaksi social (Nurhalimah, 2020). Konsep ini menjelaskan bahwa untuk dapat mengurangi bahkan memutus mata rantai infeksi Covid-19 seseorang harus menjaga jarak aman dengan manusia lainnya minimal 2 meter, dan tidak melakukan kontak langsung dengan orang lain, menghindari pertemuan massal (Buana, 2017).

Di dalam dunia pendidikan seluruh Negara memberlakukan pembelajaran di rumah secara daring untuk memutus jaringan virus. Sejak merebaknya pandemi yang disebabkan oleh virus Corona di Indonesia, banyak cara yang dilakukan oleh pemerintah untuk mencegah penyebarannya. Salah satunya adalah melalui surat edaran Kementrian Pendidikan dan Kebudayaan (Kemendikbud) Direktorat Pendidikan Tinggi No 1 tahun 2020 tentang pencegahan penyebaran Corona Virus Disease (Covid-19) di perguruan tinggi. Melalui surat edaran teresebut pihak Kemendikbud memberikan instruksi kepada perguruan tinggi untuk menyelenggarakan pembelajaran jarak jauh dan menyarankan mahasiswa untuk 
belajar dari rumah masing-masing (Firman \& Rahayu, 2020).

Begitu juga di Indonesia menteri pendidikan memberlakukan pembelajaran secara daring baik di tingkat sekolah dasar maupun di tingkat perguruan tinggi. IAIN langsa menerapkan pembelajaran secara daring, dimana para dosen pengajar memberikan mata kuliah secara daring. Ini didukung dengan perkembangan teknologi yang tidak terbatas pada revolusi industry 4.0 saat ini. Pembelajaran online secara efektif untuk melaksanakan pembelajaran meskipun pendidik dan peserta didik berada di tempat yang berbeda. Ini mampu menyelesaikan permasalahan keterlambatan peserta didik untuk memperoleh ilmu pengetahuan (Herliandry et al., 2020). Hal ini membuat para dosen harus menggunakan berbagai media dalam mengajar. Salah satunya menggunakan multimedia e-learning berbasis Ezvid. Salah satu yang dapat dimanfaatkan pada kegiatan pembelajaran adalah multimedia pembelajaran.

Fleksibelitas yang dimiliki oleh computer memanfaatkan pembelajaran multimedia dalam memecahkan masalah pada proses belajar seperti memasukkan bentuk-bentuk, video, elemen-elemen grafis, audio, proses, peran dan tanggung jawab lainnya. Dalam mendukung proses pembelajaran, komponen yang digunakan adalah multimedia pembelajaran. Multimedia merupakan salah satu media pembelajaran yang menggabungkan beberapa elemen media yang dipresentasikan dalam media komputer (Armansyah et al., 2019). Menurut
Hackbarth dalam (Priyanto, 2009) bahwa "Multimedia is suggested as meaning the use of multiple media formats for the presentation of information, including texts, still or animated graphics, movie segments, video, and audio information. Computerbased interactive multimedia includes hypermedia and hypertext. Hypermedia is a computer-based system that allows interactive linking of multimedia format information including text, still or animated graphic, movie segments, video, and audio. Hypertext is a non-linier organized and accessed screens of text and static diagrams, pictures, and tables."

Suyanto dalam Kurniawati \& Nita (2018) yang menjelaskan multimedia adalah pemanfaatan komputer untuk membuat dan menggabungkan teks, grafik, audio, gambar bergerak (video dan animasi) dengan menggabungkan link dan tool yang memungkinkan pemakai melakukan navigasi, berinteraksi, berkreasi, dan berkomunikasi. Multimedia juga merupakan suatu tampilan multimedia yang diracang oleh desainer agar tampilannya memenuhi fungsi menginformasikan pesan dan memiliki interaktivitas kepada penggunanya adapun interaktivitas multimedia meliputi (1) pengguna dilibatkan untuk berinteraksi dengan program aplikasi; dan (2) aplikasi informasi bertujuan agar pengguna bisa mendapatkan pilihan informasi yang diinginkan tanpa harus melahap semuanya (Damopolii et al., 2020).

Hal ini disebabkan karena dengan penggunaan media pembelajaran dapat menarik minat seseorang mengikuti pembelajaran dan menarik perhatiannya agar pembelajaran berjalan dengan baik, 
efektif, dan menyenangkan. Ini berkaitan dengan keuntungan menggunakan multimedia Menurut Nana Sudjana dan Ahmad Rivai dalam buku (Tegeh, 2015) yang mengatakan bahwa ada beberapa manfaat dalam menggunakan multimedia yaitu (1) Menumbuhkan motivasi siswa pada pembelajaran. (2) adanya warna, musik, dan grafis animasi yang dapat dilihat oleh siswa dalam belajar. (3) Menghasilkan penguatan yang tinggi. (4) sangat berguna bagi siswa yang lamban (5) pengajaran individual bisa dilaksanakan karena memiliki daya rekam yang baik (6) guru dapat melakukan pengawasan dengan lebih detail saat berjalannya pembelajaran dengan banyaknya informasi yang disajikan dengan mudah yang diatur oleh guru, dan dapat membantu pengawasan lebih dekat karena guru bisa berkontak langsung dengan peserta didiknya. Munir (Nopriyanti \& Sudira, 2015) membagi multimedia menjadi beberapa jenis atau kategori, yaitu: multimedia yang berbentuk nertwork-online (internet) dan multimedia offline/stand-alone (tradisional). Jenis jasa multimedia terdiri dari dua yaitu berdiri sendiri (offline/stand-alone), seperti pengajaran konvensional/tradisional dan terhubung dengan jaringan telekomuniksi (networkonline) seperti internet. Sistem multimedia stand-alone merupakan sistem komputer multimedia yang memiliki minimal penyimpanan/storage (harddisk, CD-ROM/ DVD-ROM/CDRW/DVD-RW) alat input (keyboard, mouse, scanner dan mic) dan alat output (speaker, monitor, LCD Proyektor). Dengan keuntungan yang dimiliki oleh multimedia maka proses belajar mengajar memiliki tujuan untuk membangkitkan minat dan motivasi peserta didik dalam proses pembelajaran supaya dapat tersampaikannya bahan ajar yang diberikan oleh pendidik untuk peserta didik yang dapat dilakukan dengan cara menggunakan media internet atau jaringan komputer. Pembelajaran yang dilakukan dengan menggunakan jaringan internet atau jaringan komputer sering disebut dengan pembelajaran E- learning.

E-learning merupakan inovasi yang dapat dimanfaatkan dalam proses pembelajaran, tidak hanya dalam penyampaian materi pembelajaran tetapi juga perubahan dalam kemampuan berbagai kompetensi peserta didik (Hartanto, 2016). Menurut Sanjaya (2012) e-learning adalah sebagai suatu pengalaman belajar yang disampaikan melalui teknologi. Sehingga pada pembelajaran e-learning siswa bisa belajar dengan sumber lainnya seperti video dan audio tidak hanya belajar dari internet. Banyak orang percaya bahwa multimedia akan dapat membawa kita kepada situasi belajar dimana "learning with effort" akan dapat digantikan dengan "learning with fun". Apalagi dalam pembelajaran orang dewasa, learning with effort menjadi hal yang cukup menyulitkan untuk dilaksanakan karena berbagai faktor pembatas seperti usia, kemampuan daya tangkap, kemauan berusaha, dan lain-lain (Elyas, 2018).

Koran (Mohammad Yazdi, 2012), mendefinisikan e-learning sebagai sembarang pengajaran dan pembelajaran yang menggunakan rangkaian elektronik (LAN, WAN, atau internet) untuk menyampaikan isi pembelajaran, interaksi, atau bimbingan. Ada pula 
yang menafsirkan e-learning sebagai bentuk pendidikan jarak jauh yang dilakukan melalui media internet. Penerapan e-learning dalam pendidikan memerlukan sumber daya yang mumpuni, khususnya sumber daya manusia sehingga pelaksanaan e-learning memerlukan literasi komputer bagi pendidik dan peserta didik. Literasi komputer merupakan istilah yang sering digunakan untuk menerangkan pengetahuan dasar yang perlu diketahui orang awam mengenai komputer. Konsep literasi komputer lebih berkaitan dengan segi praktis penggunaan komputer, bukan perancangan dan pengembangan komputer itu sendiri (Islamiyah \& Widayanti, 2016).

Pembelajaran e-learning adalah salah satu alternatif yang dapat digunakan oleh dosen untuk membuat mahasiswa lebih tertarik dan bersemangat dalam mengikuti proses pembelajaran. Banyak media-media atau software-software yang dapat digunakan pada pembelajaran e-learning salah satunya adalah Ezvid. Ezvid adalah software yang bisa merekam layar secara gratis yang dilengkapi dengan editor menyatu, dimana dapat membagi rekaman dan menambahkan teks diantara dua klip, menciptakan slideshow efek (Tegeh, 2015). Terdapat ribuan software yang beredar luas di masyarakat dunia saat ini. Beberapa software begitu familiar digunakan, akan tetapi terdapat beberapa software yang lain pula yang mungkin asing bahkan tidak dikenal sama sekali oleh para pengguna komputer. Software yang sering digunakan, jarang/tidak pernah digunakan bahkan sama sekali tidak dikenal akan sangat mempengaruhi pengguna komputer dalam penguasaan software (Isroqm, 2015). Ezvid merupakan software yang dapat merekam semua media pembelajaran $e$ learning menjadi sebuah video tutorial yang mana dosen mengajar atau melakukan proses pembelajaran seolaholah didalam kelas yang dapat dijadikan video pembelajaran atau dapat dibagi dengan beragam cara, dan untuk mahasiswa sendiri dapat menambah kemahiran dalam penggunaan teknologi.

Tyack dan Cuban mengatakan bahwa suatu teknologi akan berhasil jika teknologi tersebut fleksibel dalam mendampingi guru atau dosen dalam mengelola aspek tradisonal di kelas, pernyataan ini dikutip oleh Henniger (2004). Wilayah penelitian teknologi pembelajaran jika dijabarkan sangat luas. Perkembangan kawasan dan kegunaan teknologi pembelajaran Salah satu arahnya yaitu penelitian yang berkaitan dengan media. Dengan manfaatkan sumber-sumber baru seperti orang, bahan, pesan, peralatan, teknik dan latar yang memungkinkan seseorang untuk belajar secara terkendali dan terarah. Hal ini merupakan salah satu cirri konsep teknologi pendidikan yang diterapkan dalam sistem Pendidikan (Miarso, 2005).

Berdasarkan hasil observsi awal, mahasiswa Program Studi PIAUD memiliki Kemampuan penguasaan teknologi pembelajaran masih tergolong kurang menguasai berbagai teknologi pembelajaran. Sedangkan mereka nantinya akan dituntut menjadi seorang guru yang akan mengajar di tingkat dasar dan harus mahir berbagai aplikasi multimedia seperti yang sudah digalakkan oleh pemerintah. Ini sesuai dengan penelitian yang dilakukan oleh Sri Andayani, dkk (2007) yang memiliki judul "Upaya Peningkatan Kemampuan Mahasiswa dalam Penguasaan Teknologi 
Pembelajaran melalui Tugas Pembuatan Media Berbasis Komputer dalam Perkuliahan Pemrograman Komputer" Hasil penelitian menunjukkan terjadi peningkatan kemampuan mahasiswa terhadap penguasaan teknologi pembelajaran yang ditunjukkan dengan adanya media pembelajaran berbasis komputer yang telah disusun mahasiswa. Sebanyak 87\% mahasiswa mendapatkan nilai minimal B- atas tugas tersebut. Dukungan adanya peningkatan penguasaan teknologi pembelajaran juga diketahui dari $88 \%$ mahasiswa memberikan respon positif atas hal tersebut. Dengan Peningkatan kemampuan mahasiswa dalam penguasaan teknologi pembelajaran dan disertai dengan peningkatan hasil belajar dalam mata kuliah Pemrograman Komputer, yang ditunjukkan dengan 79\% mahasiswa mendapat nilai akhir minimal B-. Berdasarkan ulasan di atas maka peneliti tertarik untuk meneliti tentang apersepsi mahasiswa terhadap penerapan multimedia e-learning berbasis Ezvid di Program Studi Pendidikan Islam Anak Usia Dini Institut Agama Islam Negeri Langsa".

\section{METODE}

Penelitian ini menggunakan pendekatan penelitian kuantitatif deskriptif. Pengertian penelitian kuantitatif menurut Sugiyono adalah "penelitian berupa angka-angka dan analisis-analisis menggunakan statistik." (Sugiyono, 2011). Metode penelitian kuantitatif deskriptif yaitu penelitian dengan cara mencari informasi tentang gejala-gejala yang ditemukan, kemudia di definisikan dengan jelas tujuan yang ingin dicapai, serta merencanakan pendekatannya, dan mengumpulkan data sebagai bahan yang digunakan untuk membuat laporan. Penelitian ini menggunakan angka mulai dari pengumpulan data, penafsiran data serta hasilnya oleh karena itu penelitian ini menggunakan penelitian kuantitatif. Penelitian ini dideskripsikan secara deduksi yang dimulai dari teori-teori umum, lalu dilakukan observasi untuk menguji validitas keberlakuan teori tersebut dan kemudian ditariklah kesimpulan. Kemudian dijabarkan secara deskriptif karena hasilnya akan diarahkan untuk mendeskripsikan data yang diperoleh untuk menjawab rumusan masalah.

Populasi adalah objek yang berasal dari suatu wilayah tertentu yang memenuhi syarat berkaitan isu dari suatu penelitian (Riduwan, 2015). Populasi dalam penelitian ini yaitu seluruh mahasiswa PIAUD yang berjumlah 145. Mengingat jumlah populasi yang sangat besar. Maka peneliti mengambil sampel dari populasi. Sampel adalah bagian dari suatu populasi yang memiliki ciri-ciri dengan keadaan yang akan diteliti (Riduwan, 2015). Pengambilan sampel dilakukan dengan menggunakan teknik simple random sampling. Simple random sampling yaitu teknik pengambilan sampel yang dilakukan secara acak (Riduwan, 2015). Teknik pengambilan sampel dalam penelitian ini menggunakan teknik acak dimana diambil sebanyak 59 sampel dari Program Studi PIAUD yang mengikuti mata kuliah Praktek Ibadah.

Teknik pengumpulan dalam penelitian ini adalah Angket. Menurut Sugiyono Teknik pengumpulan data yang dilakukan dengan cara memberikan sejumlah pertanyaan atau pernyataan dinamakan angket atau koesioner (Sugiyono, 2011). Dalam 
penelitian ini untuk memperoleh responden atau hal-hal yang ingin diketahui digunakan angket. Pada penelitian ini angket digunakan untuk melihat respon mahasiswa terhadap implementasi multimedia e-learning berbasis Ezvid.

Instrumen yang akan digunakan peneliti dalam penelitian ini adalah angket. Angket dalam penelitian menggunakan skala likert dimana ada 4 alternatif jawaban yaitu, sangat setuju, setuju, tidak setuju dan saangat tidak setuju. Angket yang diberikan disebar melalui google foam. Dengan link https://docs.google.com/forms/d/e/1FAIp dinyatakan dalam rentang $0-100$. Berikut ini rumus untuk mengetahui persentase hasil dari angket responden menurut Sartika dalam Azwar (Azwar, 2012) :

Ket :

P : Frekuensi

$\mathrm{N}$ : Responden

F : Angka Persentase informasi dari QLScTPVXrDDrVxTyMeypcWntI9NGzNFUiEjiX06kGc4iJuMw/viewform - Agar proses penyusunan data dapat ditafsirkan secara mendalam kita menggunakan teknik analisis data. Analisis data menggunakan pengujian secara sistematis untuk menentukan bagiannya.

Data yang diperoleh secara umum akan diperoleh dengan bantuan excel. Analisis data dilakukan sejak data diperoleh dari hasil angket oleh peneliti. Data hasil angket

$$
P=\frac{F}{N} x 100 \%
$$

Analisis Mengenal dan Mengerti multimedia e-learning berbasis ezvid, Multimedia E-Learning Berbasis Ezvid. Kemudian 37 mahasiswa memberi respon

Berdasarkan hasil angket yang peneliti yang setuju, 18 mahasiswa tidak setuju dan sebarkan kepada 59 responden, di dapat 1 orang mahasiswa sangat tidak setuju. bahwa 2orang mahasiswa sangat setuju jika mereka sudah mengenal dan mengerti

Tabel 1. Data Hasil Mengenal Dan Mengerti Multimedia E-Learning Berbasis Ezid

\begin{tabular}{lllll}
\hline Kriteria & $\begin{array}{l}\text { Sangat } \\
\text { Setuju }\end{array}$ & Setuju & Tidak Setuju & $\begin{array}{l}\text { Sangat Tidak } \\
\text { Setuju }\end{array}$ \\
\hline Jumlah Mahasiswa & 2 & 37 & 18 & 1 \\
Persentase & $3,4 \%$ & $63,8 \%$ & $31 \%$ & $1,8 \%$ \\
Kriteria & Sebagian & Sebagian & Hampir & Sebagian \\
& Kecil & Besar & Setengahnya & Kecil \\
\hline
\end{tabular}

Analisis Tidak Adanya Kesulitan Dalam bahwa 1orang mahasiswa sangat setuju Mengoperasikan Multimedia E-Learning bahwasanya tidak ada kesulitan dalam Berbasis Ezvid mengoperasikan multimedia e-learning

Berdasarkan hasil angket yang peneliti berbasis ezvid, Kemudian 31 mahasiswa sebarkan kepada 59 responden, di dapat memberi respon yang setuju, 23 mahasiswa 
tidak setuju dan 3 orang mahasiswa sangat ditabulasikan dalam bentuk table di bawah tidak setuju. Respon mahasiswa dapat ini:

Tabel 2. Data Hasil Tidak Adanya Kesulitan Dalam Mengoperasikan Multimedia E-Learning Berbasis Ezvid

\begin{tabular}{lllll}
\hline Kriteria & $\begin{array}{l}\text { Sangat } \\
\text { Setuju }\end{array}$ & Setuju & $\begin{array}{l}\text { Tidak } \\
\text { Setuju }\end{array}$ & $\begin{array}{l}\text { Sangat Tidak } \\
\text { Setuju }\end{array}$ \\
\hline Jumlah Mahasiswa & 1 & 31 & 23 & 3 \\
Persentase & $1,7 \%$ & $53,4 \%$ & $39,7 \%$ & $5,2 \%$ \\
Kriteria & Sebagian & Sebagian & Hampir & Sebagian \\
& Kecil & Besar & setengah & Kecil \\
\hline
\end{tabular}

Analisis Fasilitas Di Rumah yang menunjang aksesmultimedia e-learning Menunjang Pengakses Multimedia $E$ - berbasis ezvid, Kemudian 26 mahasiswa Learning Berbasis Ezvid memberi respon yang setuju, 24 mahasiswa

Berdasarkan hasil angket yang peneliti tidak setuju dan 5 orang mahasiswa sangat sebarkan kepada 59 responden, di dapat tidak setuju.

bahwa 3 orang mahasiswa sangat setuju Respon mahasiswa dapat ditabulasikan bahwasanya fasilitas di rumah mereka dalam bentuk table di bawah ini:

Tabel 3 Data Hasil Fasilitas Penunjang

\begin{tabular}{lllll}
\hline Kriteria & $\begin{array}{l}\text { Sangat } \\
\text { Setuju }\end{array}$ & Setuju & Tidak Setuju & $\begin{array}{l}\text { Sangat } \\
\text { Tidak } \\
\text { Setuju }\end{array}$ \\
\hline $\begin{array}{l}\text { Jumlah } \\
\text { Mahasiswa }\end{array}$ & 3 & 26 & 24 & 5 \\
$\begin{array}{l}\text { Persentase } \\
\text { Kriteria }\end{array}$ & $\begin{array}{l}5,2 \% \\
\text { Sebagian } \\
\text { Kecil }\end{array}$ & $\begin{array}{l}44,8 \% \\
\text { Hampir } \\
\text { setengah }\end{array}$ & $\begin{array}{l}41,4 \% \\
\text { Hampir } \\
\text { setengah }\end{array}$ & $\begin{array}{l}8,6 \% \\
\text { Sebagian } \\
\text { Kecil }\end{array}$ \\
\hline
\end{tabular}

Analisis Multimedia E-Learning Berbasis ezvid adalah media pembelajaran yang Ezvid sebagai Media Pembelajaran Yang tepat diterapkan di IAIN Langsa, Kemudian Tepat 40 mahasiswa memberi respon yang setuju,

Berdasarkan hasil angket yang peneliti 12 mahasiswa tidak setuju dan 1 orang sebarkan kepada 59 responden, di dapat mahasiswa sangat tidak setuju. Respon bahwa 4 orang mahasiswa sangat setuju mahasiswa dapat ditabulasikan dalam bahwasanya Multimedia e-learning berbasis bentuk table di bawah ini:

Tabel 4. Data Hasil Multimedia e-learning berbasis ezvid adalah media pembelajaran yang tepat diterapkan

\begin{tabular}{lllll}
\hline Kriteria & $\begin{array}{l}\text { Sangat } \\
\text { Setuju }\end{array}$ & Setuju & $\begin{array}{l}\text { Tidak } \\
\text { Setuju }\end{array}$ & $\begin{array}{l}\text { Sangat Tidak } \\
\text { Setuju }\end{array}$ \\
\hline Jumlah Mahasiswa & 4 & 40 & 12 & 1 \\
Persentase & $7 \%$ & $70,2 \%$ & $21,1 \%$ & $1,7 \%$ \\
Kriteria & Sebagian & Sebagian & Sebagian & Sebagian \\
& Kecil & Besar & Kecil & Kecil \\
\hline
\end{tabular}


Analisis Kemudahan Materi Yang Ezvid adalah media pembelajaran yang Disampaikan Dalam Multimedia $\boldsymbol{E}$ - mudah dipahami, Kemudian 31 mahasiswa Learning Berbasis Ezvid memberi respon yang setuju, 18 mahasiswa

Berdasarkan hasil angket yang peneliti tidak setuju dan 1 orang mahasiswa sangat sebarkan kepada 59 responden, di dapat tidak setuju. Respon mahasiswa dapat bahwa 8 orang mahasiswa sangat setuju ditabulasikan dalam bentuk table di bawah bahwasanya Multimedia e-learning berbasis ini:

Tabel 5. Data Hasil Kemudahan Materi Yang Disampaikan Dalam Multimedia E-Learning Berbasis Ezvid

\begin{tabular}{lllll}
\hline Kriteria & $\begin{array}{l}\text { Sangat } \\
\text { Setuju }\end{array}$ & Setuju & $\begin{array}{l}\text { Tidak } \\
\text { Setuju }\end{array}$ & $\begin{array}{l}\text { Sangat Tidak } \\
\text { Setuju }\end{array}$ \\
\hline Jumlah Mahasiswa & 8 & 31 & 18 & 1 \\
Persentase & $13,8 \%$ & $53,4 \%$ & $31 \%$ & $1,8 \%$ \\
Kriteria & Sebagian & Sebagian & Sebagian & Sebagian \\
& Kecil & Besar & Kecil & Kecil \\
\hline
\end{tabular}

Analisis Kebergunaan Penerapan berguna di dalam mempelajari mata kuliah, Pembelajaran Multimedia E-Learning Kemudian, 45 mahasiswa memberi respon Berbasis Ezvid yang setuju, 7 mahasiswa tidak setuju dan

Berdasarkan hasil angket yang peneliti tidak ada mahasiswa yang sangat tidak sebarkan kepada 59 responden, di dapat setuju. Respon mahasiswa dapat bahwa 6orang mahasiswa sangat setuju ditabulasikan dalam bentuk table di bawah bahwasanya penerapan pembelajaran ini:

multimedia e-learning berbasis ezvid

Tabel. 6 Data Hasil Penerapan Pembelajaran Multimedia E-Learning

\begin{tabular}{lllll}
\hline Kriteria & $\begin{array}{l}\text { Sangat } \\
\text { Setuju }\end{array}$ & Setuju & $\begin{array}{l}\text { Tidak } \\
\text { Setuju }\end{array}$ & $\begin{array}{l}\text { Sangat } \\
\text { Tidak } \\
\text { Setuju }\end{array}$ \\
\hline Jumlah Mahasiswa & 6 & 45 & 7 & - \\
Persentase & $10,3 \%$ & $77,6 \%$ & $12,1 \%$ & - \\
Kriteria & Sebagian & Hampir & Sebagian & Tidak Ada \\
& Kecil & seluruhnya & Kecil & Satupun \\
\hline
\end{tabular}

Analisis Ketertarikan Multimedia e- ezvid menarik bagi mereka, Kemudian 37 learning berbasis ezvid bagi Mahasiswa mahasiswa memberi respon yang setuju, 11

Berdasarkan hasil angket yang mahasiswa tidak setuju dan 2 orang peneliti sebarkan kepada 59 responden, di mahasiswa yang sangat tidak setuju. dapat bahwa 8orang mahasiswa sangat Respon mahasiswa dapat ditabulasikan setuju bahwasanya penerapan dalam bentuk table di bawah ini: pembelajaran multimedia e-learning berbasis 
Tabel 7. Data Hasil Multimedia e-learning berbasis ezvid menarik

\begin{tabular}{lllll}
\hline Kriteria & $\begin{array}{l}\text { Sangat } \\
\text { Setuju }\end{array}$ & Setuju & $\begin{array}{l}\text { Tidak } \\
\text { Setuju }\end{array}$ & $\begin{array}{l}\text { Sangat } \\
\text { Tidak } \\
\text { Setuju }\end{array}$ \\
\hline Jumlah Mahasiswa & 8 & 37 & 11 & 2 \\
Persentase & $13,8 \%$ & $63,8 \%$ & $19 \%$ & $3,4 \%$ \\
Kriteria & Sebagian & Sebagian & Sebagian & Sebagian \\
& Kecil & Besar & Kecil & Kecil \\
\hline
\end{tabular}

Analisis Motivasi Menggunakan

\section{Multimedia E-Learning Berbasis Ezvid}

learning berbasis ezvid, Kemudian 33 mahasiswa memberi respon yang setuju, 18

Berdasarkan hasil angket yang peneliti mahasiswa tidak setuju dan 2 orang sebarkan kepada 59 responden, di dapat mahasiswa yang sangat tidak setuju. bahwa 4orang mahasiswa sangat setuju Respon mahasiswa dapat ditabulasikan bahwasanya mereka termotivasi terhadap dalam bentuk table di bawah ini: penerapan pembelajaran multimedia $e^{-}$

Tabel 8. Data Hasil Motivasi Mahasiswa Menggunakan Multimedia E-Learning Berbasis Ezvid

\begin{tabular}{lllll}
\hline Kriteria & $\begin{array}{l}\text { Sangat } \\
\text { Setuju }\end{array}$ & Setuju & Tidak Setuju & $\begin{array}{l}\text { Sangat } \\
\text { Tidak } \\
\text { Setuju }\end{array}$ \\
\hline Jumlah Mahasiswa & 4 & 33 & 18 & 2 \\
Persentase & $7 \%$ & $57,9 \%$ & $31,6 \%$ & $3,5 \%$ \\
Kriteria & Sebagian & Sebagian & Hampir & Sebagian \\
& Kecil & Besar & Setengahnya & Kecil \\
\hline
\end{tabular}

Analisis Penggunaan Waktu Multimedia E-Learning Berbasis Ezvid Lebih Efisien efisien, Kemudian 41 mahasiswa memberi respon yang setuju, 10 mahasiswa tidak setuju dan 2 orang mahasiswa yang sangat sebarkan kepada 59 responden, di dapat tidak setuju. Respon mahasiswa dapat bahwa 5 orang mahasiswa sangat setuju ditabulasikan dalam bentuk table di bawah bahwasanya penggunaan waktu ini:

multimedia e-learning berbasis ezvid lebih

Tabel 9. Data Hasil Penggunaan Waktu Multimedia E-Learning Berbasis Ezvid Lebih Efisien

\begin{tabular}{lllll}
\hline Kriteria & $\begin{array}{l}\text { Sangat } \\
\text { Setuju }\end{array}$ & Setuju & $\begin{array}{l}\text { Tidak } \\
\text { Setuju }\end{array}$ & $\begin{array}{l}\text { Sangat } \\
\text { Tidak } \\
\text { Setuju }\end{array}$ \\
\hline Jumlah Mahasiswa & 5 & 41 & 10 & 2 \\
Persentase & $8,6 \%$ & $70,7 \%$ & $17,2 \%$ & $3,5 \%$ \\
Kriteria & Sebagian & Sebagian & Sebagian & Sebagian \\
& Kecil & Besar & Kecil & Kecil \\
\hline
\end{tabular}


Analisis Persetujuan Mahasiswa Jika learning berbasis ezvid diterapkan di IAIN Pembelajaran Multimedia E-Learning Langsa, Kemudian 31 mahasiswa memberi Berbasis Ezvid Diterapkan Di IAIN respon yang setuju, 20 mahasiswa tidak Langsa setuju dan 3 orang mahasiswa yang sangat

Berdasarkan hasil angket yang peneliti tidak setuju. Respon mahasiswa dapat sebarkan kepada 59 responden, di dapat ditabulasikan dalam bentuk table di bawah bahwa 4 orang mahasiswa sangat setuju ini :

bahwasanya pembelajaran multimedia $e$ -

Tabel 10. Data Hasil Pembelajaran Multimedia E-Learning Berbasis Ezvid Diterapkan Di IAIN Langsa

\begin{tabular}{lllll}
\hline Kriteria & $\begin{array}{l}\text { Sangat } \\
\text { Setuju }\end{array}$ & Setuju & $\begin{array}{l}\text { Tidak } \\
\text { Setuju }\end{array}$ & $\begin{array}{l}\text { Sangat Tidak } \\
\text { Setuju }\end{array}$ \\
\hline Jumlah Mahasiswa & 4 & 31 & 20 & 3 \\
Persentase & $6,9 \%$ & $53,4 \%$ & $34,5 \%$ & $5,2 \%$ \\
Kriteria & Sebagian & Sebagian & Hampir & Sebagian \\
& Kecil & Besar & Setengahnya & Kecil \\
\hline
\end{tabular}

Analisis Pembelajaran multimedia $\boldsymbol{e}$ - learning berbasis ezvid diterapkan di learning berbasis ezvid sudah baik matakuliah, Kemudian 33 mahasiswa diterapkan pada mata kuliah memberi respon yang setuju, 19 mahasiswa

Berdasarkan hasil angket yang peneliti tidak setuju dan 2 orang mahasiswa yang sebarkan kepada 59 responden, di dapat sangat tidak setuju. Respon mahasiswa bahwa 4 orang mahasiswa sangat setuju dapat ditabulasikan dalam bentuk table di bahwasanya pembelajaran multimedia $e$ - bawah ini :

Tabel 11. Data Hasil Pembelajaran Multimedia E-Learning Berbasis Ezvid Sudah Baik Diterapkan

\begin{tabular}{lllll}
\hline Kriteria & $\begin{array}{l}\text { Sangat } \\
\text { Setuju }\end{array}$ & Setuju & Tidak Setuju & $\begin{array}{l}\text { Sangat } \\
\text { Tidak } \\
\text { Setuju }\end{array}$ \\
\hline Jumlah Mahasiswa & 4 & 33 & 19 & 2 \\
Persentase & $6,9 \%$ & $56,9 \%$ & $32,8 \%$ & $3,4 \%$ \\
Kriteria & Sebagian & Sebagian & Hampir & Sebagian \\
& Kecil & Besar & Setengahnya & Kecil \\
\hline
\end{tabular}

Analisis Pembelajaran Dengan berbasis ezvid lebih menyenangkan Menggunakan Multimedia E-Learning daripada pembelajaran konvensional, Berbasis Ezvid Lebih Menyenangkan Kemudian 27 mahasiswa memberi respon Daripada Pembelajaran Konvensional yang setuju, 28 mahasiswa tidak setuju dan

Berdasarkan hasil angket yang peneliti 1 orang mahasiswa yang sangat tidak sebarkan kepada 59 responden, di dapat setuju. Respon mahasiswa dapat bahwa 2 orang mahasiswa sangat setuju ditabulasikan dalam bentuk table di bawah bahwasanya pembelajaran dengan ini: menggunakan multimedia e-learning 
Tabel 12 Data Hasil Pembelajaran dengan menggunakan multimedia e-learning berbasis ezvid lebih menyenangkan daripada pembelajaran konvensional

\begin{tabular}{lllll}
\hline Kriteria & $\begin{array}{l}\text { Sangat } \\
\text { Setuju }\end{array}$ & Setuju & $\begin{array}{l}\text { Tidak } \\
\text { Setuju }\end{array}$ & $\begin{array}{l}\text { Sangat Tidak } \\
\text { Setuju }\end{array}$ \\
\hline Jumlah Mahasiswa & 2 & 27 & 28 & 1 \\
Persentase & $3,4 \%$ & $46,6 \%$ & $48,3 \%$ & $1,7 \%$ \\
Kriteria & Sebagian & Hampir & Hampir & Sebagian Kecil \\
& Kecil & Setengahnya & Setengahnya & \\
\hline
\end{tabular}

Analisis Rajin Belajar Dengan Adanya Kemudian 34mahasiswa memberi respon Multimedia E-Learning Berbasis Ezvid yang setuju, 17 mahasiswa tidak setuju dan

Berdasarkan hasil angket yang peneliti 2 orang mahasiswa yang sangat tidak sebarkan kepada 59 responden, di dapat setuju. Respon mahasiswa dapat bahwa 4orang mahasiswa sangat setuju ditabulasikan dalam bentuk table di bawah bahwasanya Dengan adanya multimedia $e$ - ini :

learning berbasis ezvid saya rajin belajar,

\begin{tabular}{lllll}
\multicolumn{3}{l}{ Tabel 13. Data Hasil . Rajin Belajar Dengan Adanya Multimedia E-Learning } & Berbasis Ezvid \\
\hline Kriteria & $\begin{array}{l}\text { Sangat } \\
\text { Setuju }\end{array}$ & Setuju & Tidak Setuju & $\begin{array}{l}\text { Sangat } \\
\text { Tidak } \\
\text { Setuju }\end{array}$ \\
\hline Jumlah Mahasiswa & 4 & 34 & 17 & 2 \\
Persentase & $7 \%$ & $59,6 \%$ & $29,8 \%$ & $3,6 \%$ \\
Kriteria & Sebagian & Sebagian & Hampir & Sebagian \\
& Kecil & Besar & Setengahnya & Kecil \\
\hline
\end{tabular}

Analisis Multimedia E-Learning Berbasis ezvid membawa dampak yang baik dalam Ezvid Membawa Dampak Yang Baik belajar, Kemudian 44 mahasiswa memberi Dalam Belajar respon yang setuju, 10 mahasiswa tidak

Berdasarkan hasil angket yang peneliti setuju dan 1 orang mahasiswa yang sangat sebarkan kepada 59 responden, di dapat tidak setuju. Respon mahasiswa dapat bahwa 3orang mahasiswa sangat setuju ditabulasikan dalam bentuk table di bawah bahwasanya multimedia e-learning berbasis ini:

Tabel 14. Data Hasil Multimedia E-Learning Berbasis Ezvid Membawa Dampak Yang Baik Dalam Belajar

\begin{tabular}{lllll}
\hline Kriteria & $\begin{array}{l}\text { Sangat } \\
\text { Setuju }\end{array}$ & Setuju & $\begin{array}{l}\text { Tidak } \\
\text { Setuju }\end{array}$ & $\begin{array}{l}\text { Sangat } \\
\text { Tidak } \\
\text { Setuju }\end{array}$ \\
\hline Jumlah Mahasiswa & 3 & 44 & 10 & 1 \\
Persentase & $5,2 \%$ & $75,9 \%$ & $17,2 \%$ & $1,7 \%$ \\
Kriteria & Sebagian & Sebagian & Sebagian & Sebagian \\
& Kecil & Besar & Kecil & Kecil \\
\hline
\end{tabular}


Analisis Rasa Percaya Diri Ketika presentasi menggunakan multimedia ePresentasi Menggunakan Multimedia E- learning berbasis ezvid, Kemudian 40 Learning Berbasis Ezvid mahasiswa memberi respon yang setuju, 7

Berdasarkan hasil angket yang peneliti mahasiswa tidak setuju dan 1 orang sebarkan kepada 59 responden, di dapat mahasiswa yang sangat tidak setuju. bahwa 10 orang mahasiswa sangat setuju Respon mahasiswa dapat ditabulasikan bahwasanya mahasiswa lebih percaya diri dalam bentuk table di bawah ini:

Tabel 15 Data Hasil Mahasiswa Lebih Percaya Diri Presentasi Menggunakan Multimedia E-Learning Berbasis

\begin{tabular}{lllll} 
Kriteria & $\begin{array}{l}\text { Sangat } \\
\text { Setuju }\end{array}$ & Setuju & $\begin{array}{l}\text { Tidak } \\
\text { Setuju }\end{array}$ & $\begin{array}{l}\text { Sangat } \\
\text { Tidak } \\
\text { Setuju }\end{array}$ \\
\hline Jumlah Mahasiswa & 10 & 40 & 7 & 1 \\
Persentase & $17,2 \%$ & $69 \%$ & $12,1 \%$ & $1,7 \%$ \\
Kriteria & Sebagian & Sebagian & Sebagian & Sebagian \\
& Kecil & Besar & Kecil & Kecil \\
\hline
\end{tabular}

Analisis Rekapitulasi Hasil Angket mudian hamper setengahnya tidak setuju Respon Mahasiswa Terhadap Penerapan dengan persentase 27,7\% dan sebagian kecil Multimedia E-Learning Berbasis Ezvid yang sangat tidak setuju dengan persentase

Berdasarkan tabel di bawah diperoleh 2,9\%. Jika dilihat dari nilai persentase bahwa sebagian kecil mahasiswa dengan bahwa sebagian besar mahasiswa setuju persentase $7,9 \%$ sangat setuju dengan dengan penerapan multimedia e-learning diterapkannya multimedia e-learning berbasis Ezvid di Program Studi PIAUD berbasis Ezvid, namun sebagian besar IAIN Langsa.

mahasiswa setuju dengan persentase $61,4 \%$,

Tabel 16. Rekapitulasi Hasil Angket Respon Mahasiswa Terhadap Penerapan Multimedia E-Learning Berbasis Ezvid

\begin{tabular}{lllll}
\hline & & \multicolumn{2}{c}{ Persentase Kriteria } \\
& Sangat Setuju & Setuju & Tidak Setuju & $\begin{array}{l}\text { Sangat Tidak } \\
\text { Setuju }\end{array}$ \\
\hline Jumlah & $127,70 \%$ & $982,50 \%$ & $443,00 \%$ & $46,80 \%$ \\
Rata-Rata & $7,9 \%$ & $61,4 \%$ & $27,7 \%$ & $2,9 \%$ \\
Kriteria & Sebagian & Sebagian & Hampir & Sebagian \\
& Kecil & Besar & Setengahnya & Kecil \\
\hline
\end{tabular}

\section{PEMBAHASAN}

Dari hasil analisis apersepsi mahasiswa terhadap diterapkannya multimedia e-learning berbasis Ezvid di
Program Studi PIAUD IAIN Langsa di peroleh data bahwa sebagian kecil mahasiswa dengan persentase 7,9\% sangat setuju dengan diterapkannya multimedia e-learning berbasis Ezvid di Program Studi PIAUD IAIN Langsa hal 
ini dikarenakan hanya sebagian kecil dari mahasiswa yang memiliki laptop dengan kecepatan yang baik, juga memiliki sarana dan prasarana yang mendukung seperti adanya wifi dan sinyal internet yang cepat, namun sebagian mahasiswa lagi berasal dari daerah-daerah terpencil yang tidak memiliki jaringan internet, ditambah lagi kemampuan finansial mahasiswa yang tergolong rendah sehingga mereka tidak mampu membeli laptop yang canggih.

Walaupun demikian sebagian besar mahasiswa setuju dengan diterapkannya multimedia e-learning berbasis Ezvid di Program Studi PIAUD IAIN Langsa, hal ini terbukni dengan nilai persentase $61,4 \%$ yang didapat dari hasil angket, selanjutnya hampir setengahnya tidak setuju dengan persentase $27,7 \%$ dan sebagian kecil yang sangat tidak setuju dengan persentase $2,9 \%$. Jika dilihat dari nilai persentase bahwa sebagian besar mahasiswa setuju dengan penerapan multimedia e-learning berbasis Ezvid di Program Studi PIAUD IAIN Langsa. Sehingga respon mahasiswa terhadap penerapan multimedia e-learning berbasis Ezvid di Program Studi PIAUD IAIN Langsa sebagian besar mahasiswanya setuju.

Kemudian berdasarkan angket terbuka yang peneliti sebarkan melalui google foam di peroleh beberapa kelebihan dan kekurangan penerapan multimedia e-learning berbasis Ezvid pada mahasiswa Program Studi PIAUD. Adapun kelebihannya yaitu mahasiswa dapat belajar aplikasi ezvid dengan sangat asik dan menyenangkan, mahasiswa lebih percaya diri mempresentasikan hasil kerja menggunakan multimedia e-learning berbasis ezvid, menambah pengetahuan mahasiswa di bidang kemampuan teknologi, mempermudah pembelajaran secara daring, disamping kelebihan namun banyak juga kekurangan yang berdasarkan respon mahasiswa yaitu sinyal internet, dikarenakan mahasiswa PIAUD tidak semua tinggal di kota, banyak yang tinggal dipedalaman yang membuat kesulitan mencari jaringan internet, mahasiswa kekurangan dalam segi finansial seperti tidak punya laptop,Aplikasi di Laptop yang tidak mendukung menggunakan aplikasi Ezvid, Keterbatasan fasilitas wifi sehingga kurang menunjang menggunakan aplikasi ezvid.

\section{SIMPULAN}

Apersepsi mahasiswa terhadap penerapan multimedia e-learning berbasis Ezvid di Program Studi PIAUD IAIN Langsa di peroleh data bahwa bahwa sebagian kecil mahasiswa dengan persentase $7,9 \%$ sangat setuju dengan diterapkannya multimedia e-learning berbasis Ezvid di Program Studi PIAUD IAIN Langsa, walaupun demikian sebagian besar mahasiswa setuju dengan diterapkannya multimedia e-learning berbasis Ezvid di Program Studi PIAUD IAIN Langsa hal ini terbukni dengan nilai persentase $61,4 \%$ yang didapat dari hasil angket, selanjutnya hampir setengahnya tidak setuju dengan persentase $27,7 \%$ dan sebagian kecil yang sangat tidak setuju dengan persentase 2,9\%. Jika dilihat dari nilai persentase bahwa sebagian besar mahasiswa setuju dengan penerapan multimedia e-learning berbasis Ezvid di Program Studi PIAUD IAIN Langsa. Sehingga respon mahasiswa terhadap penerapan multimedia e-learning berbasis Ezvid di Program Studi PIAUD 
IAIN Langsa sebagian besar mahasiswanya setuju.

\section{DAFTAR PUSTAKA}

Arief Kresna dan Juni Ahyar. (2020). Pengaruh Physical Distancing dan Social Distancing Terhadap Kesehatan Dalam Pendekatan Linguistik. 21(1), 1-9.

Armansyah, F., Sulton, S., \& Sulthoni, S. (2019). Multimedia Interaktif Sebagai Media Visualisasi DasarDasar Animasi. Jurnal Kajian Teknologi Pendidikan, 2(3), 224-229. https://doi.org/10.17977/um038v2i32 019p224

Azwar, S. (2012). Reliabilitas dan Validitas. Yogyakarta: Pustaka Pelajar.

Buana, D. R. (2017). Analisis Perilaku Masyarakat Indonesia dalam Menghadapi Pandemi Covid-19 dan Kiat Menjaga Kesejahteraan Jiwa. Sosial Dan Budaya, Fakultas Syariah Dan Hukum Universitas Islam Negeri (UIN) Syarif Hidayatullah Jakarta, 53(9), 1689-1699. https://doi.org/10.1017/CBO9781107 415324.004

Damopolii, V., Bito, N., \& Resmawan, R. (2020). Efektivitas Media Pembelajaran Berbasis Multimedia Pada Materi Segiempat. ALGORITMA Journal of Mathematics Education, 1(2), 74-85. https://doi.org/10.15408/ajme.v1i2.1 4069

Elyas, A. H. (2018). Penggunaan Model Pembelajaran E-Learning dalam Meningkatkan Kualitas Pembelajaran. Jurnal Warta, 56(04), 1-11.
Firman, F., \& Rahayu, S. (2020). Pembelajaran Online di Tengah Pandemi Covid-19. Indonesian Journal of Educational Science (IJES), 2(2), 81-89. https://doi.org/10.31605/ijes.v2i2.659

Hartanto, W. (2016). Penggunaan ELearning sebagai Media Pembelajaran. Jurnal Pendidikan Ekonomi, 10(1), 1-18.

Henniger, M. L. (2004). The Teaching Experience. An Introduction To Reflective.

Herliandry, L. D., Nurhasanah, Suban, M. E., \& Kuswanto, H. (2020). Pembelajaran Pada Masa Pandemi Covid-19 Luh. Jurnal Teknologi Pendidikan, 22(1), 65-70.

Islamiyah, M., \& Widayanti, L. (2016). Efektifitas Pemanfaatan E-Learning Berbasis Website Terhadap Hasil Belajar Mahasiswa STMIK Asia Malang Pada Mata Kuliah Fisika Dasar. Jurnal Ilmiah Teknologi Informasi Asia, 10(1), 41-46. https://doi.org/ISSN: 0852-730X

Isroqm, A. (2015). Pemilihan Software Aplikasi Untuk Pembuatan Media Pembelajaran Interaktif (Studi Kasus : Aplikasi PowerPoint). Jurnal Dosen Universitas PGRI Palembang., 1317-1336.

Kurniawati, I. D., \& Nita, S.-. (2018). Media Pembelajaran Berbasis Multimedia Interaktif Untuk Meningkatkan Pemahaman Konsep Mahasiswa. DoubleClick: Journal of Computer and Information Technology, 1(2), 68. https://doi.org/10.25273/doubleclick. v1i2.1540

Miarso, Y. (2005). Menyemai Benih 
Teknologi Pendidikan. Jakarta: Prenada Media.

Mohammad Yazdi. (2012). E-learning sebagai Media Pembelajaran Interaktif Berbasis teknologi Informasi. Jurnal Ilmua Foristek, 2 (1)(1), 143-152.

Nopriyanti, N., \& Sudira, P. (2015). Pengembangan multimedia pembelajaran interaktif kompetensi dasar pemasangan sistem penerangan dan wiring kelistrikan di SMK. Jurnal Pendidikan Vokasi, $5(2)$.

https://doi.org/10.21831/jpv.v5i2.641 6

Nurhalimah, N. (2020). Upaya Bela Negara Melalui Sosial Distancing dan Lockdown Untuk Mengatasi Wabah COVID-19 (Efforts to Defend the Country Through Social Distancing and Lockdown to Overcome the COVID-19 plague). SSRN Electronic Journal, 19. https://doi.org/10.2139/ssrn.3576405

Priyanto, D. (2009). Pengembangan Multimedia Pembelajaran Berbasis Komputer. JURNAL PEMIKIRAN ALTERNATIF KEPENDIDIKAN, 14(1), 1-13.

Riduwan. (2015). Metode \& amp; Teknik Menysusn Proposal Penelitian. Bandung: Alfabeta.

Sanjaya, W. (2012). Media Komunikasi Pembelajaran. Jakarta: Kencana
Sekolah (Home Schooling)", dalam Jurnal ULTIMA Infosys. Universitas Multimedia Nusantara, Vol. IV(No. 1.).

Setiawan, A. R. (2020). Lembar Kegiatan Literasi Saintifik untuk Pembelajaran Jarak Jauh Topik Penyakit Coronavirus 2019 (COVID-19). Edukatif: Jurnal Ilmu Pendidikan, 2(1), 28-37. https://doi.org/10.31004/edukatif.v2i 1.80

Sri Andayani, Kuswari Hernawati, S. (2007). Upaya Peningkatan Kemampuan Mahasiswa Dalam Penguasaan Teknologi Pembelajaran Melalui Tugas Pembuatan Media Berbasis Komputer Dalam Perkuliahan Pemrograman Komputer Jurusan Pendidikan Matematika Fmipa Universitas Negeri Yogyakarta. Vol. 3(No.2).

Sugiyono. (2011). Metode Penelitian Kuantitatif, Kualitatif, dan R\&D. Bandung:Alfabeta.

Tegeh, I. M. (2015). Desain Multimedia Pembelajaran. Yogyakarta: Media Akademi.

Yusup, D. K., Badriyah, M., Suyandi, D., \& Asih, V. S. (2020). Pengaruh bencana Covid-19, pembatasan sosial, dan sistem pemasaran online terhadap perubahan perilaku konsumen dalam membeli produk retail. Http://Digilib. Uinsgd. Ac. Id, 1(1), 1-10. 